\title{
Teacher Candidates' Involvement with Reading Interventions in High Needs Schools: Wrestling with the Everyday
}

\author{
Steve Sider \\ Wilfrid Laurier University \\ Christina Belcher \\ Redeemer University College
}

\begin{abstract}
The demands on new teachers as they enter the teaching profession are extensive and deep-rooted. This article provides insight into how faculty within a teacher education program in Ontario, Canada considered one service program emphasis and how it shed light into the everyday world of teacher candidates as they wrestled with the everyday activity of trying to support struggling readers. We identify this process of forging relationships and developing professional skills as we examine the experiences and reflections of teacher candidates as they journey through their involvement with the program. As such, we take Dorothy Smith's (2005) perspective that the everyday world is problematic. Those things which we take for granted, and assume to be obvious, or have been assumed by reading research to be normative, are not necessarily so.
\end{abstract}

\section{Introduction}

In contrast to other sociologies, it [institutional ethnography] . . . is one of inquiry which begins with the issues and problems of people's lives and develops inquiry from the standpoint of their experience in and of the actualities of their everyday living. (Smith, 2002, p.18)

Over the last decade there has been robust discussion on the significance of literacy acquisition in elementary classrooms (McDaniel, 2004; Bereiter \& Scardamalia, 2005; Kugler \& Flessa, 2007). Within these classrooms, the increasing importance placed on assessment, high yield strategies, and standardized tests can put immense pressure on teachers to meet the needs of every child (Grayson, 2007; Valli \& Buese, 2007; Leithwood \& McAdie, 2007). New teachers are particularly challenged when confronted with the wide variety of literacy measures, resources, and high stake assessment pressures (Cherubini, 2009) promoted via text-books, media, board officials, and provincial/state government directives. Add to this complicated mix, the realities of working in high need schools and it is little wonder that new teachers often experience significant stress.

In order to prepare new teachers for these challenging situations, we, both professors in universities in Ontario, Canada, undertook a program to provide opportunities for teacher candidates to experience literacy scaffolding and reading assessment in high need schools in a large city in central Canada. Teacher candidates are students enrolled in a Faculty of Education, preparing to be teachers. The teacher candidates were enrolled in a university education course focused on how to support struggling readers. As the course initially developed, it became apparent that talking and learning about struggling readers in the university context did not capture the day-to-day classroom experiences of these children or those working with them. Out of these early observations a program was borne to engage in the everyday world of children who struggle in reading and the teachers who work with them. Four Literacy Improvement Teachers (LITs) in high need schools in a large school board in central Canada showed enthusiasm about partnering in this journey by engaging teacher candidates with their struggling readers, and their schools became the sites for the program. We termed this project as the Most Valuable Person (MVP) reading support program. The MVP program paired students in grades 3-6 with a reading mentor who was a teacher candidate from the 
university. Teacher candidates maintained enrollment in the reading course at the university while involved in the MVP program.

Teacher candidates volunteered to engage struggling readers in their normal everyday life in respective schools at least once every week over the course of a university term. Such a project is reflective upon the quote by Smith which initiates this paper: Participants engage the everyday lives and experiences of the learners as they struggle to read, and in doing so, reflect upon their own abilities to provide restorative assistance. In reflecting on the launch of this program, both of us wondered whether the actual work on the ground in classrooms would cause thinking beyond that of delivering scaffolding and strategies: Would our candidates be changed in their dispositions regarding their views of struggling readers? Would short-term interventions have any effects, and if so, would they be enduring? Would the LIT teachers find our students a real help or an inconvenience? Hence, we entered the program with some angst, both for our students and for ourselves.

Struggling readers were defined as having adequate general language ability but weaknesses in literacy-related areas, often having difficulty in accurately and fluently reading printed words (Carnine et al, 2006). The school board in which this program takes place identifies struggling readers as generally performing at a Level 2 (C) reading level and who do not have an Individual Educational Plan (IEP) for specific reading disabilities. Prior to and during their service learning time in the schools, teacher candidates were given support and direction as needed by the site-based LIT. Both in and out of the university classroom, we also assisted the teacher candidates in developing reading-based activities which would be engaging and connected to pre-determined individual learning objectives. As well, we had frequent debrief meetings and in-class discussions with the teacher candidates as we engaged them in reflective activities. After a number of years of reports from the teacher candidates and from the Literacy Improvement Teachers regarding the perceived value of the experience, and after refining the training and resources, we decided to further investigate the impact of the intervention in light of its value to teachers in training, and to struggling readers and their teachers in high need schools. This paper is reflective of our ongoing discourse and relational work following the first three years of the program.

What we discovered was not so much about the impact of the program intervention but the ways in which the teacher candidates made sense of the everyday experiences of working with struggling readers.

\section{Interacting with the Literature}

There are three bodies of literature particularly relevant to this study. First, we examine the literacy preparation which teacher candidates experience in university teacher education programs or in school contexts. Second, we explore literature that focuses on volunteers in reading contexts. Third, we review the work of Dorothy Smith $(2005,2006)$ in situating how we might consider the everyday experiences of those who were involved with the MVP program.

In teacher education programs, there has been a significant focus on how to prepare teacher candidates, as well as new teachers, so that they may support the broad literacy needs of the future students they will work with (e.g. Courtland \& Leslie, 2010). Within this broad scope of literature, there have been critical examinations of what is meant by literacy and how to teach (for) literacy (e.g., McLean \& Roswell, 2013). The work of Grossman et al. (2000) suggests that new teachers use the literacy tools that they learned in their university teacher education program, particularly those that were supported with practical strategies and application. The work of Grossman et al. (2000) illustrates the importance of not just providing academic knowledge of literacy and language instruction but to provide concrete strategies to support the theoretical knowledge. At the same time, Grossman et al. (2000) suggest that simply providing practical strategies without a conceptual framework does not provide new teachers with the critical lens they need to consider new literacy strategies, curriculum materials, or techniques. Thus, the practical experience of working with readers needs to be coupled with the conceptual development that occurs in university teacher education programs.

Similarly, White and Hill (2008) examined university-based and school-based literacy experiences for teacher candidates. White and Hill posit that teacher candidates who had the opportunity to learn about, and practice, literacy instruction in school contexts had a deeper understanding of the challenges and complexities 
of literacy education than teacher candidates who learned about literacy instruction solely in the university context. The work of Grossman et al. (2000) and White and Hill (2008) help situate the MVP program which provided an opportunity for teacher candidates to "put into practice" the literacy instruction approaches and concepts which they were learning in the university classroom.

Although there is research literature that considers how volunteers contribute to reading improvement for students (e.g., Elbaum, Vaughn, Hughes, Watson \& Moody, 2000; Slavin, Lake, Davis \& Madden 2009; Wasik, 1998, 2011; Wolfgong, 2008), there is limited literature that considers the reflections and reading attitudes of both the volunteer and the student in the learning process. Although the studies noted here do include volunteer situations they differ in significant ways to the goals and outcomes of our study. The work of Wasik (1998, 2011), emerging from the Center for Research on the Education of Students Placed At Risk (CESPAR) at Johns Hopkins University has good scope and contour for informing our study. In reviewing 16 voluntary tutoring programs, it was concluded that volunteers may be able to contribute to reading development of children, but that further work on how was needed. It is our view that since the study focused on effectiveness by equivalent treatment and comparison groups, consisting of adult volunteers, it did not consider the everyday life of the volunteer/student relationship and attitudinal stance toward learning that Dorothy Smith $(2005,2006)$ considers to be most significant in educational settings.

In the research done by Elbaum et al. (2000), they concluded that adult and student interventions on a voluntary basis were helpful, but the focus was more on the use of the Reading Recovery Program than on the specific relational reflections of the student and volunteer; a focus once again given more attention by Smith (2005, 2006). The work of Slavin et al. (2009) and Wolfgong (2009) focus more on specific approaches such as using phonics and poetry for reading growth, once again not considering the impact of teacher candidate volunteers reflecting upon and engaging in dialogue with students regarding the learning experience. Although these studies considered the benefits, challenges, and value of having volunteers work with struggling readers, they also were focused more on the technique of the intervention rather than the relational learning for both volunteer and student as the working relationship developed. It is to this end that our study may assist in the larger body of knowledge on the effectiveness of student volunteers in a teaching program being focused on the relational and reflective aspects of working with those who struggle. Our study is informed by the literature on volunteer reading programs but unfolded within a framework which aimed to better understand the experiences of the teacher candidates and children involved in the reading program.

In our review of the literature, we found that numerous studies focused on a reading intervention program, rather than a reading intervention posture. Few studies we found had the same trajectory of inquiry as our study, that is, using volunteers to assist reflective and attitudinal stances that would make a way for literacy acquisition for struggling readers. In this study, we focus on the relational, reflective interaction between the student's need and the teacher candidate's ability to meet that need. This is not to say that we do not equip the volunteers with the 'tools' and strategies available for supporting reading development in the elementary classroom. This is done in the university course that parallels the MVP project. However, the knowledge development that takes place within the course is furthered by the dialogic and reflective interaction between teacher candidates, university faculty, students, and Literacy Improvement Teachers.

\section{The Ethnographic 'Everyday' of Dorothy Smith}

Institutional ethnography is committed to discovering beyond any one individual's experience, and the work by Dorothy Smith $(2005,2006)$ became core to understanding the communal dynamics of volunteering in the school setting. For Smith, the 'social' is defined as focus on actual people, actual activities, and the contexts in which those activities are coordinated (Smith, 2005, p.70). In her work, Smith stresses that language is the key to understanding the 'other' within an ongoing dialogic conversation. This process opens the act of meaning making between teacher and student where the student can be active in understanding how language is organized within the context of experiences that are lived (Smith, 2005, pp.68-69). Simply put, children make sense out of meaning making within a context of learning, not out of word recognition alone. Experience and divergence of perspective must be given a space to thrive. Smith's work is crucial to our understanding and meaning making as teachers in this work. In short, her perception of language learning in 
the classroom is that "Language organizes our sensory communities as inter-individual territories; that is, it organizes a reciprocal relation between speaker and learner (and, I would add, between writer and reader) in which their differentiated experiences and perspectives intersect in a world known and named in common" (2005, p.78). In such a study, we feel it is significant that we and our students cannot be 'separated' from the research. In reflecting on it, engaging it, and learning from it in order to alter it, we become changed by doing so.

From such considerations, the initial key research question was identified as: What is the impact of a short-term reading intervention on the reading attitudes of children involved in the MVP reading project? As we analyzed the data collected from within the everyday discourse that emerged from visits over a period of time, we recognized the development of a deeper theme. That is, the way teacher candidates were experiencing the challenges of working with struggling readers represented a way of making sense of the teaching world they were beginning to enter. In approaching this question, central to our research is the position held by Dorothy Smith. Smith has coined the term problematic as a key element within ethnographic study. Smith has appropriated the term problematic from Louis Althusser (1971, p.32) to locate the discursive organization of a field of investigation that is larger than a specific question or problem (Smith, 2005, p.38). For Smith, the dialogic narrative voices within the community of the research field are significant in addressing this problematic. As Smith (2006) states, institutional ethnography "is not meant as a way of discovering the everyday world as such, but of looking out beyond the everyday to discover how it came to happen as it does"(p.3). Thus, we used the everyday world experiences of the teacher candidates as a lens to examine how and why it was that they were having these experiences as they were.

As we undertook this research, simultaneously the schools in which we worked were also investigating the effect of gender issues on boys' literacy learning. Gender issues in education have been examined extensively (Newkirk, 2002; Booth, 2002; Spence, 2008; Sokal, Thiem, Crampton \& Katz, 2009) but usually without considering the perceptions of the teacher candidate and student in dialogic conversation. In pairing students with teacher candidates who act as reading mentors, we also thought it would be interesting to ask the teacher candidates the question: Is the gender of the university mentors perceived as a factor in the receptivity of the children to the mentors? Thus, this study includes the insights of teacher candidates as to whether their gender impacted the children's reading attitude. This intersects with the literature on volunteer mentors and gender (Giles, 2008). Although many agree that there is a difference between genders in literacy acquisition (Chatterii, 2006; Kelly, 2007; Lietz, 2006; Gray, Peng, Steward \& Thomas, 2004; Ontario Ministry of Education, 2004; Gurian \& Stevens, 2005), the actual conclusions of the mosaic behind gender differences in literacy outcomes is mixed and requires a whole ethnographic view of contributors incorporating a larger ethnographic and communal perspective (Klinger, Shuhla \& Wade-Woolley, 2009). Current work done on institutional ethnography and literacy also indicates the value of literacy as a "social accomplishment, the value of many people's work", often also includes hidden curriculum not formerly assessed (Parkinson \& Stooke, 2012). Thus, we nurtured interest in knowing how the intervention impacted the teacher candidate's sense of preparedness for teaching.

\section{Methodology and Organization}

University research ethics clearance was obtained for this project and a mixed methods research framework was used in the study. Teacher candidates at the university volunteered for involvement in the MVP reading support program during the university semester in which they were taking a course on reading support for struggling readers. Twenty-eight teacher candidates who volunteered for the program agreed to participate in the research project. The majority of the participants were female $(23 / 28)$, which impacted the opportunity to explore the perceived effect of gender in the reading intervention process.

For this particular research project, two schools were selected to be hosts for the university mentors. The two schools were chosen due to their proximity to each other, previous experience in running the program, and the leadership and involvement of the Literacy Improvement Teachers. The schools were located in a large city in Ontario and had been identified as 'poor performing' schools by the school board. The annual provincial standardized literacy assessment (Educational Quality and Accountability Office, EQAO) placed the schools as two of the lowest performing in the urban area. These schools also held in 
common the same base for assessing struggling readers that involved use of the Developmental Reading Assessment (DRA) program. The DRA is used in many Canadian schools boards and has its base in the reflective work of Fountas and Pinnell (1996, 1999, 2001, 2009). This form of benchmark assessment included the diagnostic tools of informing teaching practices, such as running records, leveled books, San Diego or Slosson word lists, text gradients and phonetic decoding strategies while also considering process and meaning making for students in grades 3-6 (approximately aged 8-11), reading at a grade or more below their current grade level.

The DRA is traditionally administered on an annual or semi-annual basis. The phonetic portion of the test measures nine categories of reading behavior and six types of errors. Skills measured by the DRA test include rhyming, alliteration, segmentation, and phonemic awareness. Other literacy understandings tested include letter naming, word-list reading, spelling, decoding, analogies, structural analysis, and syllabication. Words per minute for contextual reading are tested under fluency. The test also measures vocabulary, comprehension, and reading engagement skills. Canadian correlations of the DRA to the work of Fountas and Pinnell are outlined in Appendix A.

University teacher candidates received reading intervention training in the semester in which the MVP program took place. This consisted of training done within the participating elementary schools and from a university course which had a focus on struggling readers. The university course is an eight week, senior level course on reading intervention and support. The course consists of 1.5 hour class periods which occur twice per week. It is taken by teacher candidates who are in a concurrent education program and completed in either the fourth or fifth year of the teacher education program. The course provides an overview of the different reasons why children struggle in reading, common assessment tools, and strategies to support struggling readers. The key goal of the course is to provide teacher candidates with an understanding of the challenges which struggling readers experience and to equip them with a knowledge base by which to support these readers.

Teacher candidates began working with children in January. Initial orientation was completed onsite at the schools so that the hosts and participants in this research could meet key administrators and teachers and develop an awareness of the context of their work. Teacher candidates began their mentoring mid-January and completed the mentoring in mid-March. The task of mentoring struggling readers involved once per week sessions of approximately 40 minutes. The teacher candidates, as mentors, were partnered with one or two children and remained with the child(ren) for the entirety of the program.

A mixed methodology for examining the research questions included qualitative methods, utilizing focus groups and interviews, as well as quantitative methods employing questionnaires which the teacher candidate participants completed. Multiple focus group meetings with the teacher candidates, multiple interviews with the Literacy Improvement Teachers, and multiple student reading questionnaires were completed. Of the 28 teacher candidates in the research project, 19 were involved in the focus groups. Three literacy teachers from the host schools were involved in interviews.

Sixty elementary school students were involved in the reading program and were selected by the literacy and classroom teachers. The students were identified as struggling readers by the classroom and literacy teachers; as indicated earlier, struggling readers are those students who would not have an Individual Education Plan specifically for reading and generally are performing at a Level 2 (C) in reading. Thirty-five students completed questionnaires at the beginning and end of the MVP program. The questionnaires had been developed by the partnering school board. The questionnaire which was completed at the beginning of the MVP program focussed on students' initial attitudes toward reading and the types of books and settings they identified with reading (see Appendix B). At the end of the program, students completed a similar survey but which also included questions addressing the experience of working with a mentor (see Appendix C).

The completion of the questionnaire was supported by the teacher candidates through oral dialogue between the mentor and student, and reflective notes were made by the teacher candidate after meeting with the student. In keeping with the work of Smith (2005, 2006), the Literacy Improvement Teachers, teacher candidates, and faculty involved utilized the questionnaire as a means to better understand the process of learning that the students had experienced. 


\section{Initial Understandings: Student Input to Having a Reading Mentor}

As indicated, the students who were being mentored completed a school board-developed questionnaire, of which the first six questions dealt with attitude toward reading and the second part which dealt with the child's perception of working with a teacher candidate mentor. In regard to the first six questions, we measured the change in response between the two surveys that the children completed. We were interested in seeing if there was any change in the reading attitude over the two month period that the teacher candidate worked with the child. There were numerous variables which we could not control (e.g. involvement of other people such as parents/caregivers or teachers in developing this attitude), but given the sample size (35 student questionnaires), the data does provide some insight into how reading mentorship and scaffolding can support increased positive attitude toward reading.

Although we saw small changes in the student responses to most of the first six questions in the questionnaire, we did see a general overall increase in positive responses to the questions (see Appendix D, Figures 1-6). At the end of the program, students were generally more positive about reading, about being read to, about considering themselves good readers, and about reading when they had free time. One specific area stands out; students were generally more positive about being read to at the completion of the program. This indicates support for the research noted by Shirley Brice Heath $(1982,2008)$ that struggling readers would benefit from being read to orally, noting the significance of stories and early use of narratives in supporting later language ability. In some individual cases, students went from answers which were neutral or in disagreement, to strongly agreeable. Again, this is evidence that the opportunity to work with a mentor contributed to the child's positive attitude toward reading.

An interesting result from the second questionnaire was the positive response of the majority of the children to the teacher candidate mentors (see Appendix D, Figures 7-10). Ninety-seven percent of the children indicated that they strongly or mildly agreed with the statement that they liked having a student mentor. Likewise, $92 \%$ of the elementary students indicated that they agreed that the mentor had helped with their reading attitude. In addition, $86 \%$ of the students agreed, either strongly or mildly, that the teacher candidate had helped them improve their reading. Lastly, 86\% strongly agreed that they would like to keep working with a mentor. Based on these responses, it would seem that the children felt positive about the experience of having the university teacher candidate work with them.

Teacher candidates and literacy teachers agreed that the program was an effective one in supporting reading development. However, as conversations continued, they also saw the limitations of short term interventions, and were willing and eager to discuss ways in which the program could be more effective in the long run. This would not have occurred had we left the study as 'mere data' without vigorous ethnographic engagement. What is perhaps most interesting is that our research began with a desire to examine the effectiveness of a short-term reading support program but developed into something richer. We began to see that teacher candidates were starting to make sense of what it meant to be a teacher. As we questioned and interacted in this process, the teacher candidates began to identify and unveil some of the presuppositions they held about children, teachers, learning, and teaching. We turn to these questions and insights in the next section.

\section{Unpacking Teacher Candidate Voices: Moving From Perception to Understanding}

For the teacher candidates, the opportunity to work with a student provided valuable experience in developing an emerging sense of reading problems, resources, and an awareness of community. Since the selected elementary school students were stuggling readers, it provided the teacher candidate mentors with an ideal population with which to work. Narratives between children, faculty, Literacy Improvement Teachers, and teacher candidates provided insight into the perceptions of all parties. The next section of these findings will deal with the reflective comments that were collected from individual participants, and conclude with a larger ethnographic perspective. In the responses which follow, all names are pseudonyms.

As teacher candidates and children experienced the building of community, the opportunity to work together became more comfortable. Teacher candidates commented that at the introductory session, when they first met the student they would be working with for the next two months, there was some anxiety from 
both the teacher candidates and the students. One teacher candidate, Chad commented, "The first session was shaky" and this sentiment was shared by many of the teacher candidates. However, it quickly became apparent that the teacher candidates and students were building relationships which made the sense of space more comfortable. The students seemed to be highly motivated in subsequent meetings and teacher candidates noticed this increasing engagement, as Julie (teacher candidate) stated, "I was amazed at their [children] enthusiasm." Another teacher candidate, Simon, commented that, "They [children] seem to enjoy the more intimate atmosphere and the added attention they receive." It seemed clear that the early jitters which accompanied the early formation of community were disappearing and that a level of comfort was developing.

These early statements by teacher candidates caused us to reflect on the everyday experiences of the teacher candidates and students as they built community. We, as faculty, began to ask questions such as, "Why was Julie 'amazed'?" and "Why did the teacher candidates sense a growing comfort level?" We wondered why the teacher candidates would pick up on the student excitement? The sense of wonder that comes with learning isn't removed from children so we questioned whether the teacher candidates approach to the social context was a perspective that 'this is going to be tough, it's inner city and that the students are not going to want to learn.' We raised these questions with the teacher candidates and were able to reflect together on what preconceived ideas and perceptions we brought with us to the everyday world of teaching.

Not only did the teacher candidates note the change which occurred in students' attitudes, but they also benefitted by having opportunity to experience those 'aha' moments when children overtly experience learning. Fatima, one teacher candidate, stated, "This is a fantastic program! ... I bave been able to see the incredible learning jump that can occur when a light bulb turns on and a child suddenly understands something... This kind of attention is invaluable." Teacher candidates began to have robust conversations between themselves and with faculty as to what was working well in their reading support areas. This added to the excitement; teacher candidates were developing community amongst themselves as they listened and supported each other's experiences, both the successes and failures. The community developed as relationships formed: between students and teacher candidates, and between teacher candidates and university faculty.

Clearly, the positive experience of being with each other, around a reading activity, was key for the teacher candidates and children. Indicators that the children were enjoying the program included times when children wanted to skip recess so they could read with their mentor, regularly asking when their mentor was going to come, wanting to continue to play reading games after the designated time was done, and the desire of other children to participate in the program who had not been selected. Comments by the teacher candidates reflected their comfort zones and introduction to the world of teaching struggling readers, feeling confident in that environment, and making meaning of their tasks. This broad space then began to include other dimensions of the teaching and learning experience for all parties. In particular, the LIT and classroom teachers were also developing a comfort zone which embraced the additional support the teacher candidates provided as part of the learning community.

For the literacy and classroom teachers, having university teacher candidate mentors accessible to provide one-on-one support each week to a struggling reader was an ideal way to supplement the work that was being done in the classroom. Often, LIT and classroom teachers commented that the teacher candidates support filled the 'gap' that the teacher did not have the time to fill. Teachers commented that their time was often taken up with at risk readers so those who struggled would not have received the support needed if not for the teacher candidate. Classroom teachers made comments such as "Bring them [teacher candidates] on in!" and "Wow, I'm impressed!" to the Literacy Improvement Teachers; comments that also served to open doors to further collaborative discussion between teacher candidates, teachers, and LITs. These seasoned teachers, leaders within their schools, contributed to the community-building and positive environment through their positive support of the teacher candidates. Their welcoming of the teacher candidates, and sense of support, contributed to the teacher candidates' increasing sense of self-confidence.

As the sessions continued to proceed, teacher candidates were asked to comment on their perspective of gender, between their own and the children they were working with, and what impact they perceived this having on the reading relationship. This question emerged mid-term after the students and teacher candidates had time to develop a working relationship and build community. The question was prompted by one of the LITs who wanted to pursue the issue of gender due to his involvement in a boardinitiated program focused on boys and reading. So, again, as we considered the everyday practices of 
teaching, we responded to emerging needs and questions - such as perceptions of how the gender of the teacher candidates may affect the building of community with the students. Due to the duration of the study and the inexperience of the teacher candidates, it was difficult to ascertain in great detail whether the gender of the mentor affected the reading development of the child. However, this study does provide insight into how the mentors perceived gender affecting the reading intervention. Interestingly, the male mentors felt that gender was a factor in the pairing while the majority of the female mentors did not think it was a factor, or at least only minimally.

When discussing the issue of gender, one male teacher candidate (Joseph) commented,

My student [male] felt comfortable with me and was able to share important details about learning with me due to the fact that I was male. He also requested me to return and if I could not, then he preferred another male teacher.

In considering this comment, we questioned how Joseph came to perceive that the student he was working with "felt comfortable" with him and how he could make the assumption that the student shared details of learning because he was a male? Was this about student preferences or student needs? Was it the teacher candidate's comfort level or the child's? Further, we wondered, if the student did indeed feel more comfortable, did that also mean that the student learned better?

Another male teacher candidate (Chad) stated that, "I felt that I was given respect quickly by my male students more quickly than by my female student." Again, we asked, why would the teacher candidate perceive this? What was it about the relationship, or the teacher candidate's background, which would lead to this belief? These types of questions allowed us, and the teacher candidates, to delve more deeply into the experience of teaching and how we make sense of teaching and learning.

Female teacher candidates expressed different insights into whether gender did or did not play a role in the building of community. For example, one female teacher candidate (Savonne) stated that, "They [male students] were very willing to share with me stories and developments in their life... and I think they just loved having someone who was there to focus solely on them." Another candidate (Karen) was adamant that gender had no affect on the relationship-building process, "I was paired with two boys... I don't think. my gender had any effect on the program or reading..." One female teacher candidate (Dawn) did indicate that being of the same gender could help with making a 'connection' with the student:

It was easy to make connections to the story that they [girls] would understand since I can relate on a gender basis. I don't think. my gender would stop me from doing the same with boys, it just makes it far easier when you bave yet another way to relate to the student.

One further comment made by a female teacher candidate regarding gender raised many questions. Krystina stated that:

One thing I did notice is that a lot of the boys we work, with come from single-parent families, almost all of who have a male "father" figure missing from their lives, and some had a skewved perception of men in general. In that way I feel it might have been beneficial for them to have a positive male role model, especially in terms of looking at their education or as a reading mentor.

Again, we became increasingly interested in how the female teacher candidates were making sense of issues of gender within teaching: Why did some female teacher candidates feel that their gender could help in making connections to stories? Why would a teacher candidate perceive that the students she was working with enjoyed having a focus solely on them? Why would a teacher candidate perceive that having a positive male role model be important to a student who may have lacked a male mentor?

These questions were interrogated with the teacher candidates as we explored our assumptions about gender, reading, and teaching. Although these comments are somewhat superficial in tone, as part of a larger communal conversation they provided thought-provoking discussion as to how these candidates and their students could do things differently in the future in ways that minimized initial presuppositions and engaged significant social issues. The comments and questions which came from these conversations really 
highlighted a hidden curriculum which develops from our perceptions and presuppositions: "Institutional ethnography begins with and takes for granted that people experience, see, and conceive things differently. . . Social relations and organization generate difference" (Smith, 2002, p. 22).

Smith (2002) argues that the contours of life, the curriculum, our family circumstances, our own presuppositions, all have an effect on our teaching practice:

The work of the sociologist is to discover these relations and to map them so that people can begin to see how their own lives and work are hooked into the lives and work of others in relations of which most of us are not aware. (p. 18)

Interestingly, teacher candidates did recognize a need to gain insight into their own backgrounds and to delve into these presuppositions to get a better sense of why they thought as they did. A more significant study related to gender would need to consider many of the variables that this study did not. However, it is just such variables that dialogic narrative inquiry within an ethnographic setting hopes to tease out.

\section{Collaborative Considerations and Conclusions: Adding the Researcher's Voice}

As researchers, we found the community dynamic changed the research (MacLure, 2003). We started by looking for answers to issues of reading and we ended up recognizing that we can't remove the researcher from the research. Our research moved to a greater focus on the experiences and the process involved with teaching and not the product. Just like teaching, research can be 'messy' as questions change and emerge. As part of this process, we recognize that the study was limited in numerous ways. For example, due to school board policies, we were not able to interview the children independently to determine their perceptions of the reading program or of the issue of gender. Instead, we had to rely on the interactive conversations and perceptions of the teacher candidate for that emergent data. As a result, our data relied on reports from the teacher candidates and the classroom and literacy teachers more than on the voices of the children themselves, which truncates Smith's $(2005,2006)$ value upon ethnographic dialectic conversations from all parties. As well, the survey data from the children was limited. There were many layered variables we were not able to engage such as the impact of others on the child's reading attitude. It was also hard to know if the favourable responses of the children toward their mentors was because of the 'love of reading' the mentors instilled or simply because the children enjoyed the opportunity to spend time outside of class or to spend time with an older, university student.

Yet, despite these limitations, there are some valuable issues that the study raises. First, the individual support which volunteers provide to struggling readers is invaluable. This was recognized not only by the teacher candidate mentors, but most strongly by the responses of classroom and literacy teachers. Teachers commented that often struggling readers do not get as much attention as needed in the regular classroom because the teacher has to focus on the lowest performing, at-risk students. As a result, the support of volunteers to work with the struggling reader is seen as highly desirable by teachers (Giles, 2008).

Children seem to be aware of the benefit that a volunteer can provide as well. The children indicated a marked increase in enjoyment when being read to in the survey. They also demonstrated a strong appreciation for the time that they had with the mentor. There was not enough evidence through this study to demonstrate that this relationship actually led to reading skill improvement or long-term positive reading attitude over time. However, if reading attitude can shift positively, as it did for many in this project, in a short period such as a semester, then it is our submission that the affect could be even more significant over a longer period of time. Relationship-building and an emerging sense of community seemed to support the enjoyment that the students and teacher candidates experienced.

Second, for university teacher candidates, the experience of working with struggling readers provides significant insight and preparation for a teaching career. Teacher candidates commented that the experience had shed light on deeper issues for consideration in the schooling community. They indicated stronger knowledge and awareness of common teaching tools available in schools such as the Developmental Reading Assessment (DRA). They also had access to resources provided by university faculty and to those provided by the literacy improvement teachers. This opportunity to explore and utilize these resources was identified 
as a significant learning opportunity by the teacher candidates. This also supports the work Grossman et al. (2000) as well as White and Hill (2008) demonstrating the importance of providing both the conceptual knowledge required to teach reading as well as the practical experience to engage with readers while in teacher education programs. We anticipate that this will lead to the further research on teacher candidates' confidence and preparation to engage struggling readers. At the same time, the teacher candidates indicated that the experience had led to many questions that they had not previously considered. Paramount amongst these questions were those surrounding effective teaching practices in high needs classes and schools, and the larger community aspects of learning engagement beyond the school walls. This demonstrates that the journey itself and the questions that were raised and interrogated, were an important part of coming to know oneself as a teacher.

Third, although we did see that there was some perceived affect related to the gender of the mentor as to the ability to support the reading ability of a student, this was not a theme which can be given much credence through this study. Work that has been done in the area of gender and education (e.g., Booth, 2002; Gurian \& Stevens, 2005) will continue to inform these discussions. It seems that, at most, gender might provide an initial, invitational opportunity by which a male student might be more receptive to a male mentor (and female student to female mentor). However, our observation has been that what really matters is the mentor's attitude and effort with the child. Gender issues seem to disappear quickly when a child perceives that the mentor is interested in him/her as a person, no matter the gender.

Education programs in universities have tremendous opportunity to prepare teacher candidates, and benefit children in high needs schools through reading programs such as the MVP reading support program. It is often challenging to get volunteers in high need schools, and universities are often removed from core city schools. From this study, and supported by the work of White and Hill (2008), we have come to believe that how we prepare teacher candidates to engage with struggling readers may require additional practicum and specialized, practical opportunities during the educational process of obtaining their degree. Thus, concerted efforts by faculties of education could provide real benefit to the children in these schools as well as providing an opportunity for teacher candidates to experience the context of these schools (Wasik, 2011; Grossman et al., 2000). We suggest that partnership reading programs that are established and run through the course of a school year, and which might even "follow" children over multiple years would provide significant benefit to the children involved.

Further research also needs to be considered in the area of dispositions which teacher candidates exhibit which might lead to improved reading attitude when working with a student, especially as these are informed by the meaning making work of Dorothy Smith (2003) and her emphasis on relational activity as being contextual to learning. Our study has made us aware that consistent reflection with each other as researchers, coupled with the reflective dialogic of our teacher candidates and Literacy Improvement Teacher partners, has created a relational accountability that keeps us all working to find the unique and special place for each student to flourish as future literacy practitioners and enablers.

In some ways, this work mirrors the work of Parker (2010) that provided opportunity for teacher candidates in a teacher education program to engage in literacy narratives. Parker (2010) determines that these literacy narratives, and the process of "telling, living, and retelling of the stories" (p. 1259) provides an opportunity for teacher candidates to wrestle with melding new knowledge with formed teacher knowledge. As universities consider these types of opportunities, the impact of the experience on the teacher candidate, as well as on the child, must be explored as a partnership in learning. Certainly, more work needs to be done regarding the question of whether the mentor's gender impacts the effectiveness of reading interventions with children. However, we must first consider the learning needs of the student, and keep this as our main goal, since our study has shown that the relational side of learning seems to defy gender perceptions.

We suggest a more in-depth study be done based on Smith's work within the scope of problematics, and done over a period of time with the inclusion of all voices in the study being represented. The MVP program is currently being revised so that we will engage children for longer time periods within these schools that may also add further contours to the relational activity core of the mentoring experience. For example, having a seasoned teacher candidate act as a 'point person' to peers for orientation and advice may provide a more timely intervention for change of scaffolding strategy than having to come back to class, discuss the problem, and then obtain some ideas that could be helpful. The structure engaged within this 
research study by the participant schools did limit this aspect of our research. Therefore, alternate ways of framing a further study would be more communally dialogic, cover a longer period of time, and would further explore the developing conversations between all parties in the study. The entire social setting could be more of a focus and there could need to be more emphasis on student voices and the conversations between all parties involved. Finally, further work needs to be done in how the system world (organization, texts, programs) of the school and the life world (relational activities within learning experiences) of the participants may assist or diminish reading acquisition. 
Appendix A: Reading A-Z Correlation Chart

\begin{tabular}{|c|c|c|c|c|c|c|c|}
\hline $\begin{array}{l}\text { Reading A-Z } \\
\text { Level }\end{array}$ & Ages & Grade & $\begin{array}{l}\text { Fountas } \\
\text { \& Pinnell }\end{array}$ & $\begin{array}{l}\text { Reading } \\
\text { Recovery }\end{array}$ & DRA & Lexile & $\begin{array}{l}\text { Criteria for Leveling } \\
\text { Reading A-Z Books: }\end{array}$ \\
\hline aa & $4-6$ & K & A & 1 & A-1 & BR-70 & $\begin{array}{ll}\text { - } & \text { Word count } \\
\text { - } & \text { Number of different } \\
\text { words }\end{array}$ \\
\hline$A$ & $4-6$ & K & A & 1 & A-1 & BR-70 & $\begin{array}{l}\text { Ratio of different } \\
\text { words to total words }\end{array}$ \\
\hline B & $4-6$ & K & B & 2 & 2 & BR-70 & frequency words \\
\hline C & $4-6$ & K & $\mathrm{C}$ & $3-4$ & $3-4$ & BR-70 & $\begin{array}{l}\text { frequency words to } \\
\text { total words }\end{array}$ \\
\hline D & $4-7$ & 1 & D & $5-6$ & 6 & $80-450$ & $\begin{array}{l}\text { frequency words to } \\
\text { total words }\end{array}$ \\
\hline E & $6-7$ & 1 & E & $7-8$ & 8 & $80-450$ & $\begin{array}{l}\text { Ratio of low- } \\
\text { frequency words to } \\
\text { total words }\end{array}$ \\
\hline$F$ & $6-7$ & 1 & F & $9-10$ & 10 & $80-450$ & $\begin{array}{ll}\text { - } & \text { Sentence length } \\
\text { - } & \text { Sentence complexity }\end{array}$ \\
\hline G & $6-7$ & 1 & G & $11-12$ & 12 & $80-450$ & 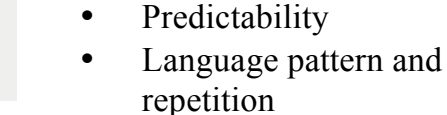 \\
\hline H] & $6-7$ & 1 & $\mathrm{H}$ & $13-14$ & 14 & $80-450$ & $\begin{array}{l}\text { Print size, spacing, } \\
\text { and number of words }\end{array}$ \\
\hline ] & $6-7$ & 1 & I & $15-16$ & 16 & $80-450$ & $\begin{array}{ll} & \text { per page } \\
\text { - } & \text { Illustration support } \\
\text { - } & \text { Concept load }\end{array}$ \\
\hline J & $6-8$ & 1 & $\mathrm{~J}$ & 17 & 18 & $451-500$ & - Topic familiarity \\
\hline R & $7-8$ & 2 & $\mathrm{~J}$ & 17 & 18 & $451-550$ & About this Chart \\
\hline 1 & $7-8$ & 2 & K & 18 & 20 & $501-550$ & \multirow{4}{*}{$\begin{array}{l}\text { This correlation chart } \\
\text { illustrates how Reading A-Z } \\
\text { levels approximately correlate } \\
\text { to other leveling systems } \\
\text { commonly found in leveled } \\
\text { reading materials. Reading A- } \\
\mathrm{Z} \text { uses objective (quantitative) } \\
\text { and subjective (qualitative) } \\
\text { Leveling Criteria to measure } \\
\text { text complexity. }\end{array}$} \\
\hline $\mathrm{WJ}$ & $7-8$ & 2 & $\mathrm{~L}$ & 19 & 24 & $551-600$ & \\
\hline $\mathbb{N}$ & $7-8$ & 2 & $\mathrm{M}$ & 20 & 28 & $551-650$ & \\
\hline 0 & $7-8$ & 2 & $\mathrm{M}$ & 20 & 28 & $601-650$ & \\
\hline P & $7-8$ & 2 & M & 28 & 28 & $601-650$ & \multirow{3}{*}{$\begin{array}{l}\text { Teachers should use their } \\
\text { professional judgment of } \\
\text { additional qualitative criteria } \\
\text { along with reader and task } \\
\text { considerations to determine if } \\
\text { an individual book at a given } \\
\text { level is appropriate for a } \\
\text { student. }\end{array}$} \\
\hline (0) & $7-9$ & 3 & $\mathrm{~N}$ & 30 & 30 & $651-690$ & \\
\hline B & $8-9$ & 3 & $\mathrm{~N}$ & 30 & 30 & $651-730$ & \\
\hline
\end{tabular}


JOURNAL OF TEACHING AND LEARNING, 2015, VOL.10, NO. 1

\begin{tabular}{lcccccc}
\hline S & $8-9$ & 3 & O & 34 & 34 & $691-770$ \\
\hline J & $8-9$ & 3 & P & 38 & 38 & $731-770$ \\
\hline U & $8-11$ & 4 & Q & 40 & 40 & $771-800$ \\
\hline V & $9-11$ & 4 & Q & 40 & 40 & $771-830$ \\
\hline W & $9-11$ & 4 & R & 40 & 40 & $801-860$ \\
\hline X & $9-11$ & 5 & S & 40 & 40 & $831-860$ \\
\hline Y & $9-11$ & 5 & T & 40 & 40 & $861-890$ \\
\hline Z & $9-11$ & 5 & U-W & N/A & 50 & $891-980$ \\
\hline
\end{tabular}

Source: http://www.readinga-z.com/correlation-chart.php 
Appendix B: Initial Questions Asked of Students

\begin{tabular}{|l|l|l|}
\hline Question & Response \\
\hline I like to read & $\begin{array}{l}\text { Strongly } \\
\text { I like to be read to }\end{array}$ & Mildly \\
\hline $\begin{array}{l}\text { I am a good reader } \\
\text { to read }\end{array}$ & \\
\hline I feel proud about what I can \\
read
\end{tabular}


Appendix C: Questions Asked at the End of the MVP Program

\begin{tabular}{|l|l|l|}
\hline Question & Response \\
\hline I like to read & Strongly \\
\hline I like to be read to & Mildly \\
\hline $\begin{array}{l}\text { When I have free time, I like } \\
\text { to read }\end{array}$ \\
I feel proud about what I can \\
read
\end{tabular}




\section{Appendix D: Graphed Responses to Questions}

Figure 1: "I like to read"

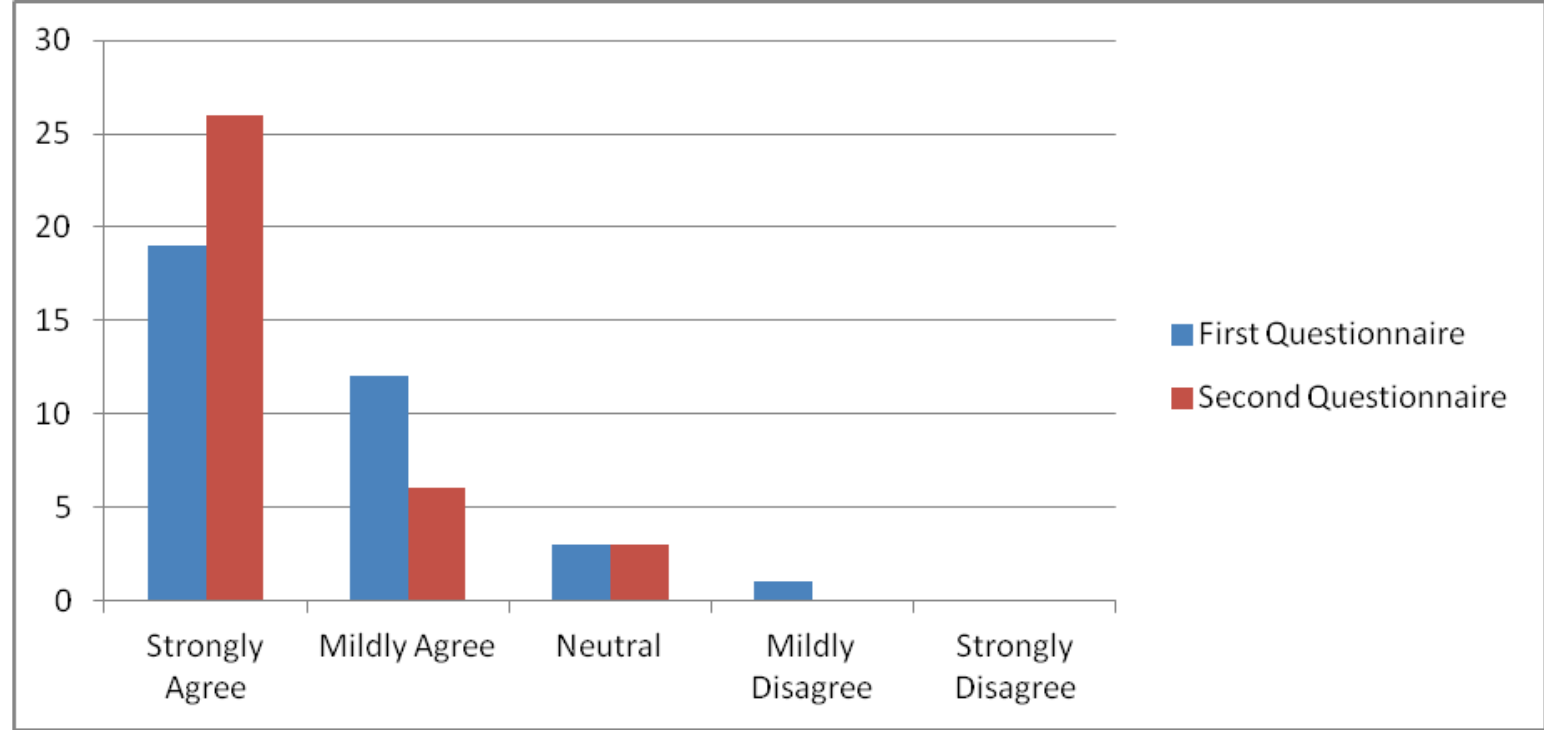

Figure 2: "I like to be read to"

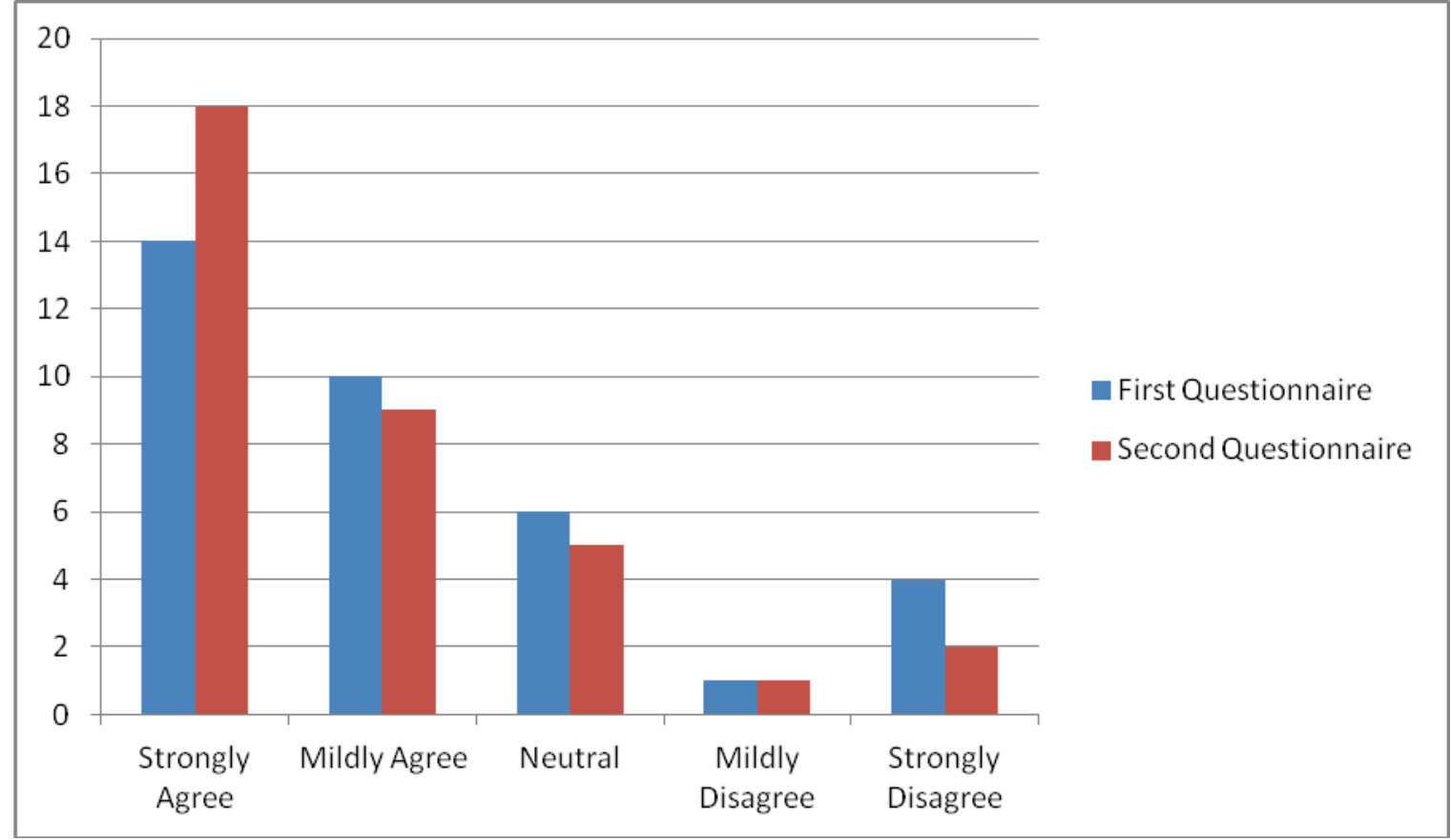

Figure 3: "I am a good reader" 


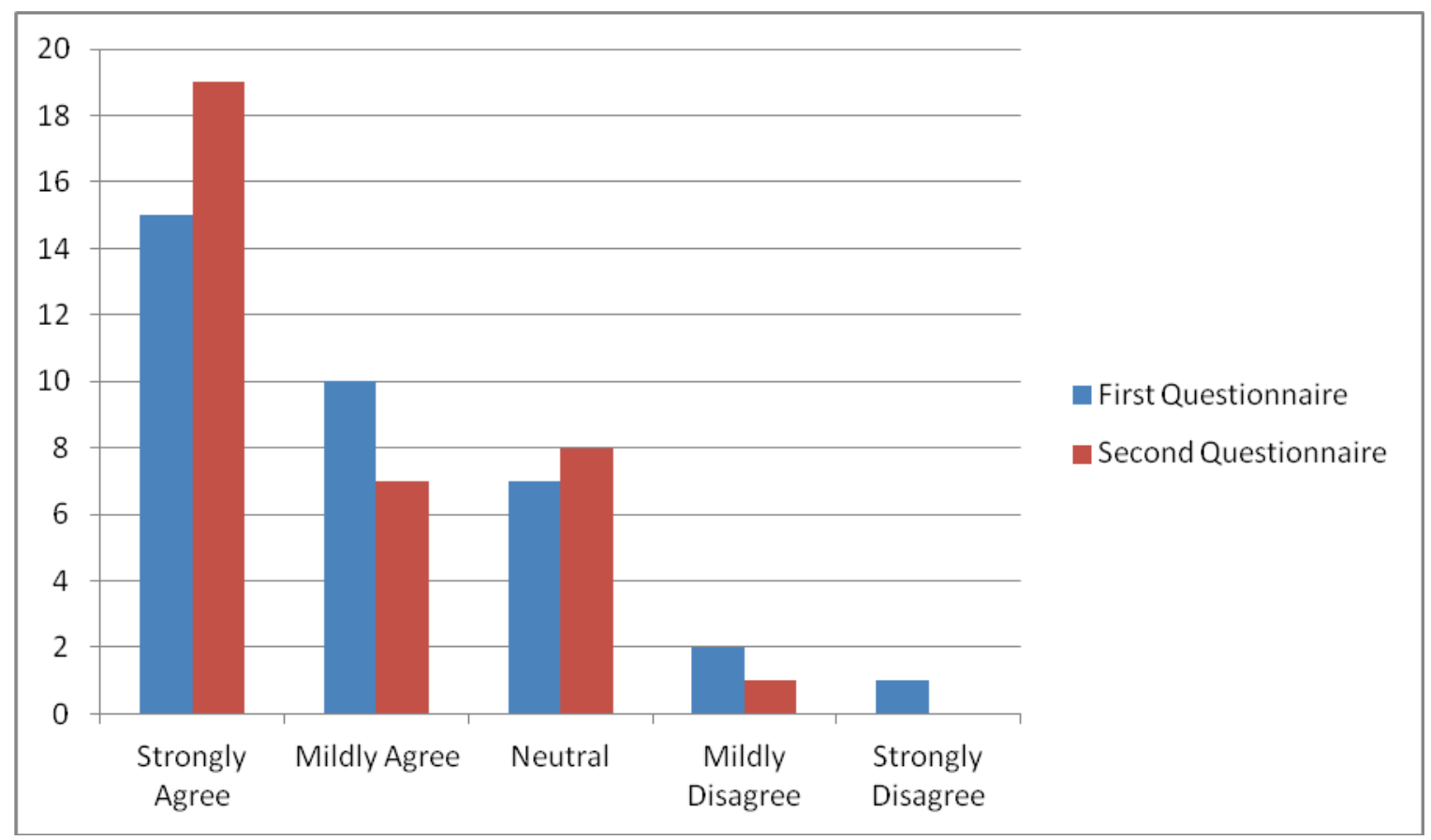

Figure 4: "When I have free time, I like to read"

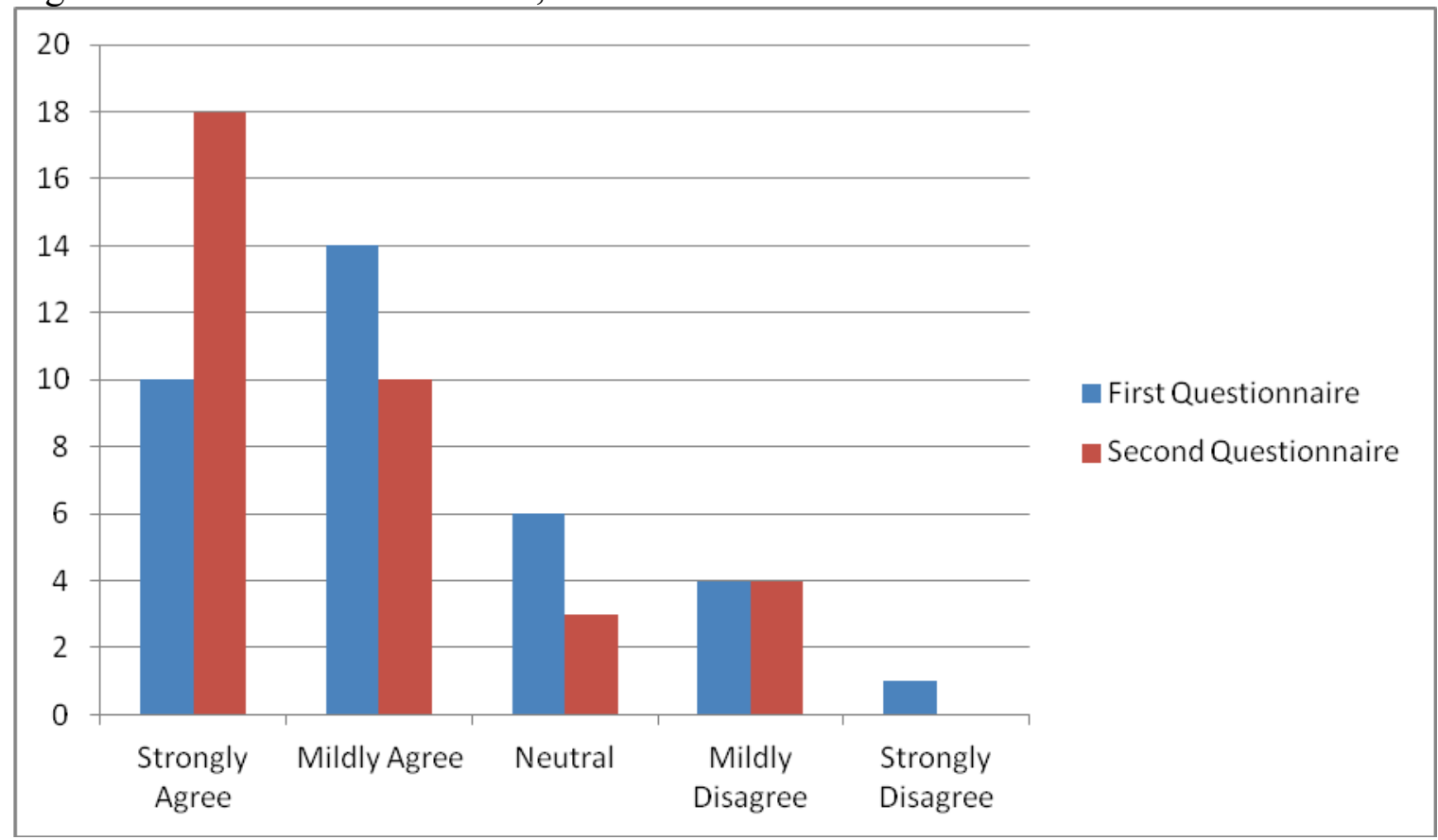

Figure 5: "I feel proud of what I can read" 


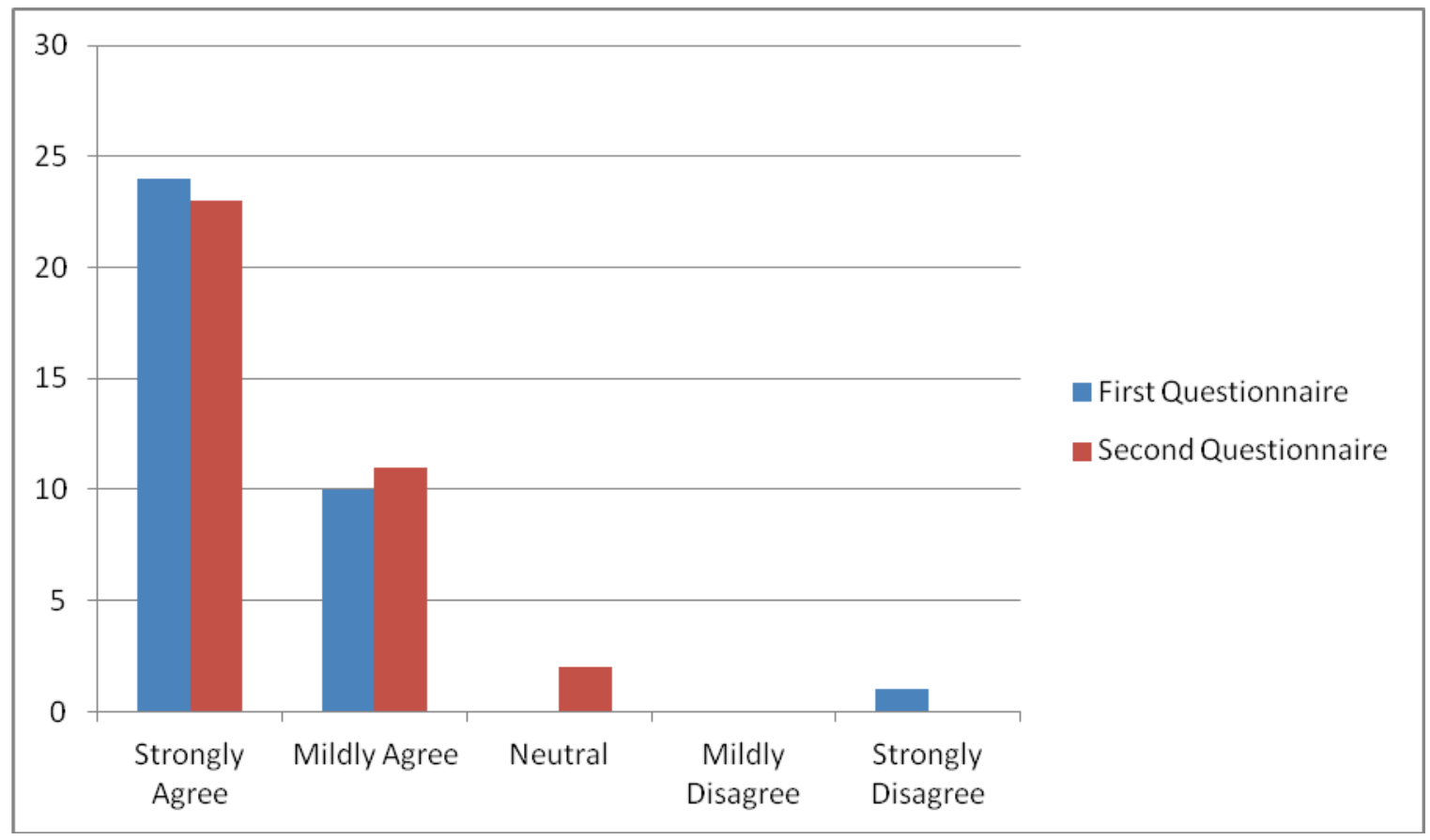

Figure 6: "Being able to read well is important to me"

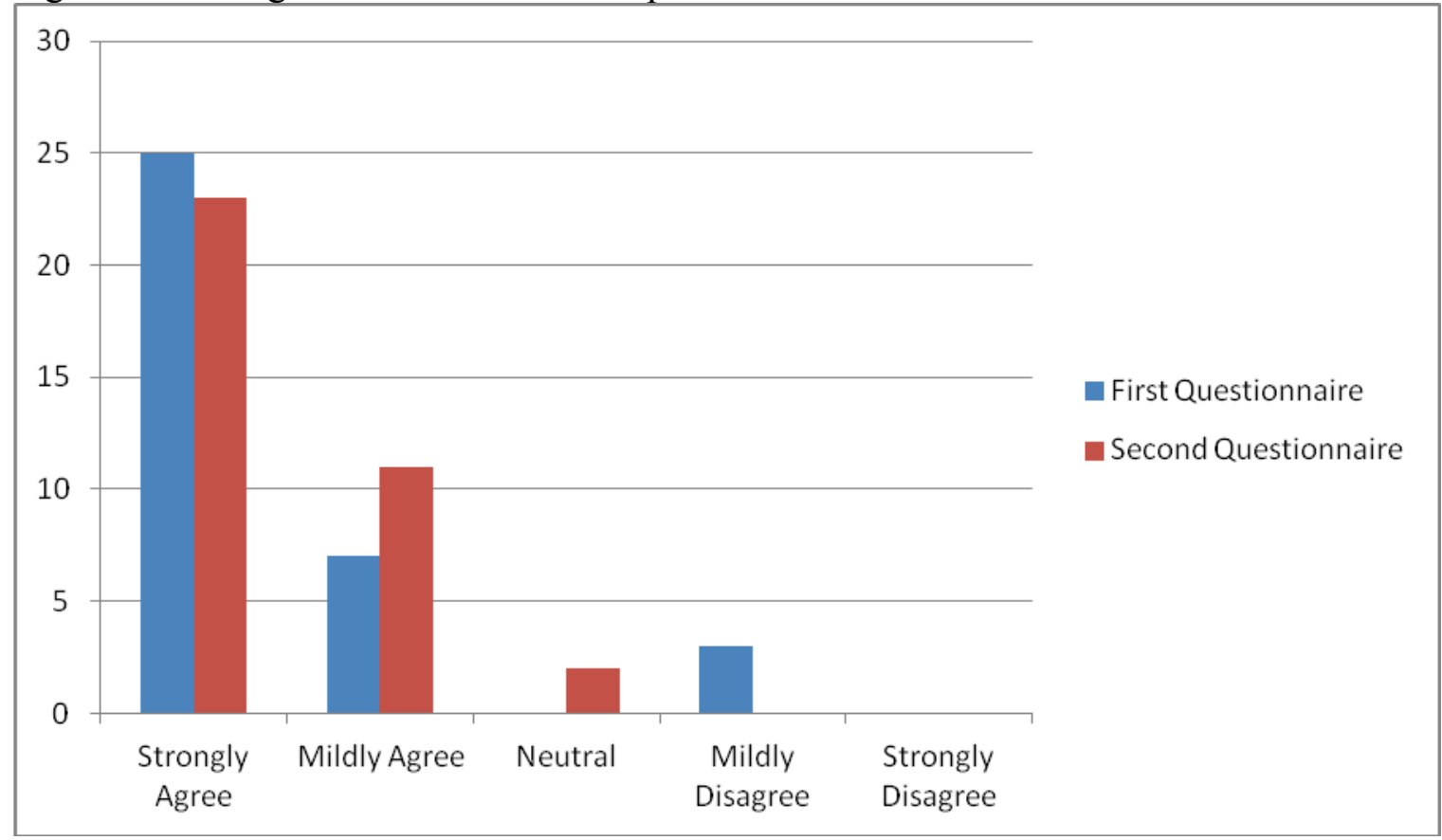


Figure 7: "I like having a student mentor"

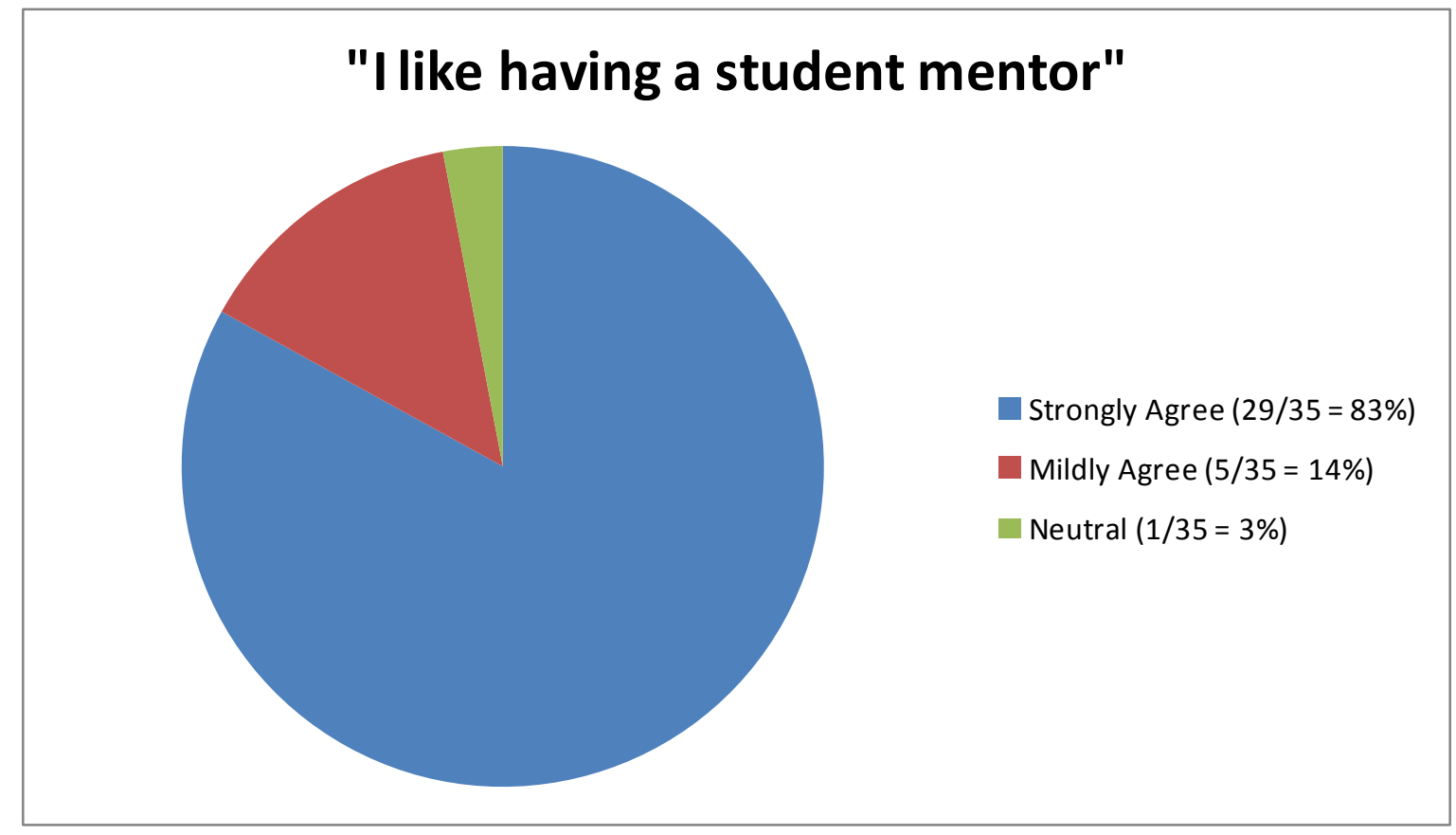

Figure 8: "This mentor has helped my reading attitude"

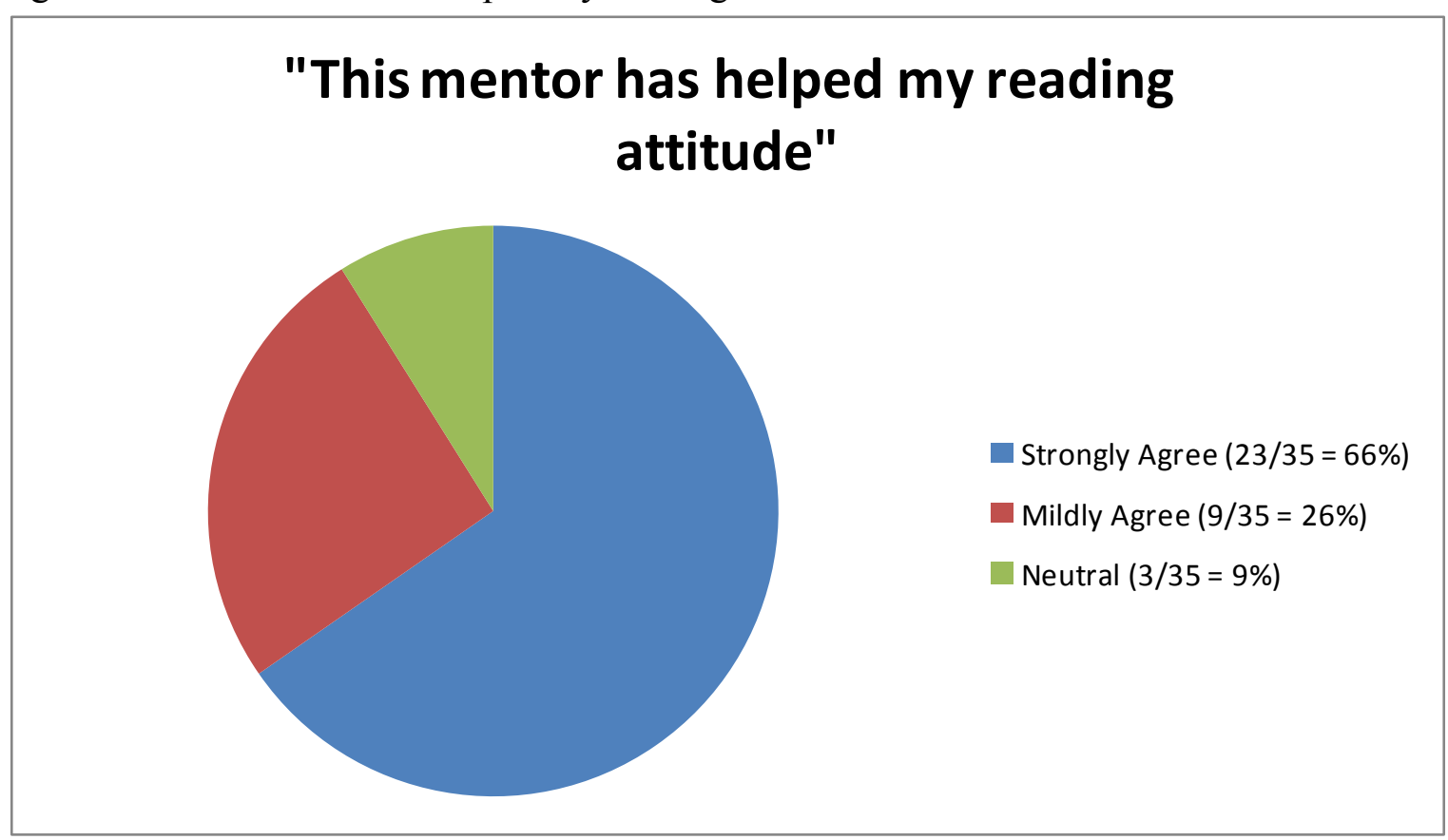


Figure 9: "This mentor has helped my reading improve"

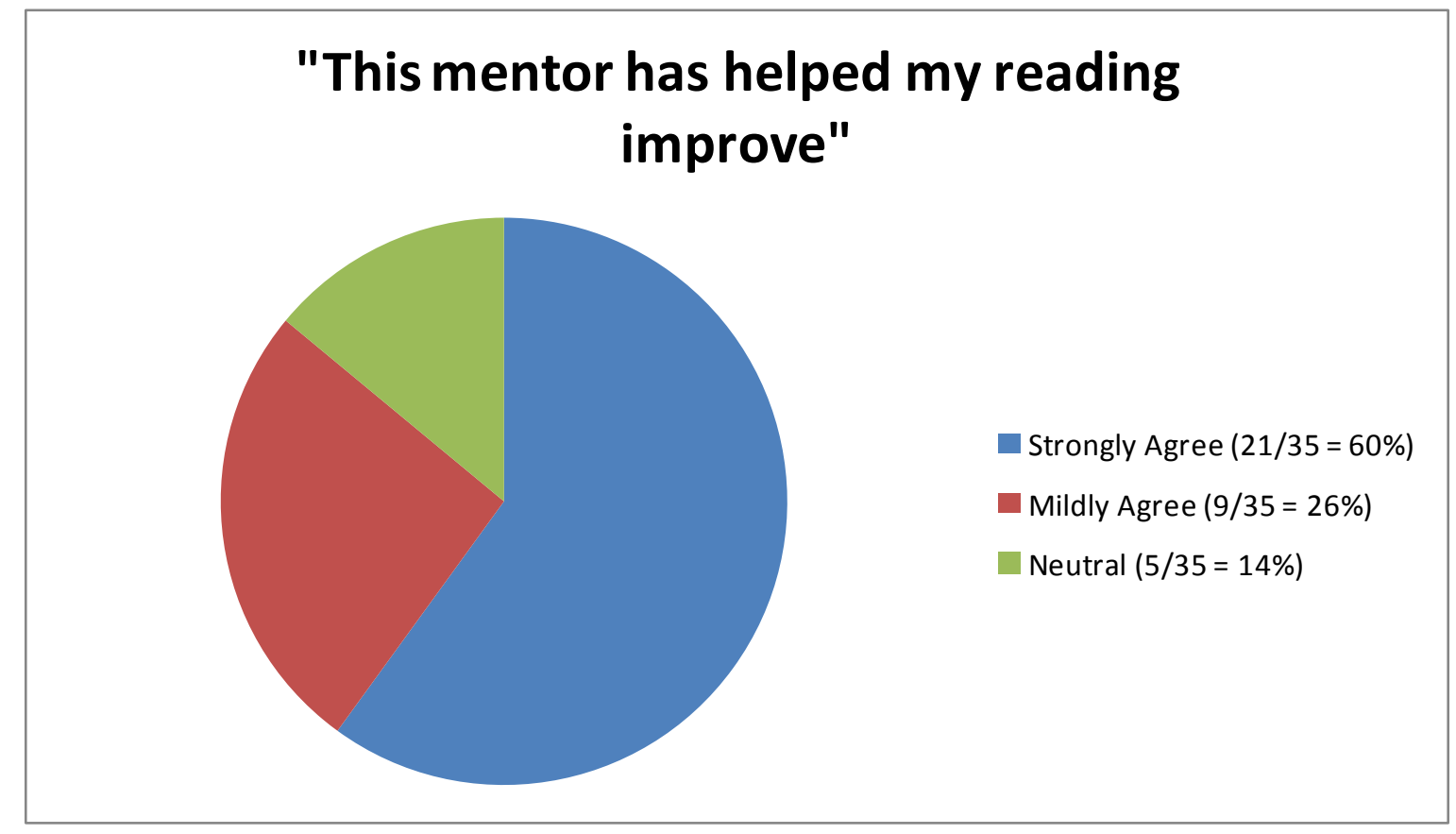

Figure 10: "I would like to keep working with a student mentor"

\section{"I would like to keep working with a mentor"}

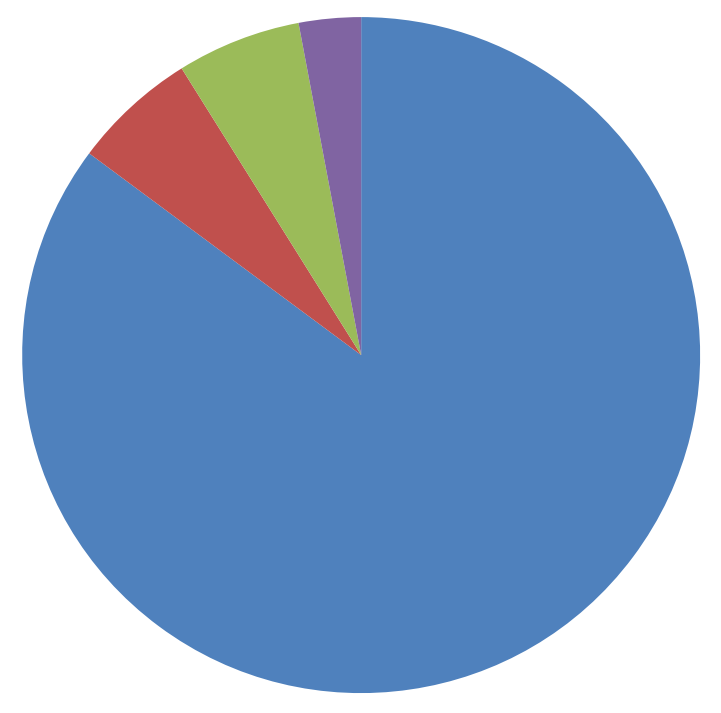

- Strongly Agree $(30 / 35=86 \%)$

Mildly Agree $(2 / 35=6 \%)$

Neutral $(2 / 35=6 \%)$

Strongly Disagree $(1 / 35=3 \%)$ 


\section{References}

Bereiter, C., \& Scardamalia, M. (2005). Technology and literacies: From print literacy to dialogic literacy. In N. Bascia, A. Cumming, A. Datnow, K. Leithwood \& D. Livingstone (Eds.). International Handbook of Educational Policy (pp. 749-761). London: Springer.

Booth, D. (2002). Even hockey players read: Boys, literacy and learning. Markham, ON: Pembroke.

Carnine, D. W., Silbert, J., Kame'enui, E. J., Tarver, S. G., \& Jungjohann, K. (2006). Teaching struggling and at-risk readers: A direct instruction approach. Upper Saddle River, NJ: Pearson Prentice Hall.

Chatterji, M. (2006). Reading achievement gaps, correlates, and moderators of early reading achievement: Evidence from the early childhood longitudinal study (ECLS) kindergarten to first grade sample. Journal of Educational Psychology, 98(3), 489-507.

Cherubini, L. (2009). Reconciling the tensions of new teachers' socialisation into school culture: A review of the research. Issues in Educational Research, 19(2), 83-99.

Courtland, M., \& Leslie, L. (2010). Beliefs and practices of three literacy instructors in elementary teacher education. The Alberta Journal of Educational Research, 56(1), 19-30.

Elbaum, B., Vaughn, S., Hughes, T., Watson, M., \& Moody, S. (2000). How effective are one-to-one tutoring programs in reading for elementary students at risk for reading failure? A meta-analysis of the intervention research. Journal of Educational Psychology, 92(4), 605-619.

Fountas, I., \& Pinnell, G. (1996). Guided reading: Good first teaching for all children. Portsmouth, NH: Heinemann.

Fountas, I., \& Pinnell, G. (1999). Voices on word matters: Learning about phonics and spelling in the literacy classroom. Portsmouth, NH: Heinemann.

Fountas, I., \& Pinnell, G. S. (2001). Guiding readers and writers grades 3-6: Teaching comprehension, genre and content literacy. Portsmouth, NH: Heinemann.

Fountas, I., \& Pinnell, G. S. (2009). When readers struggle: Teaching that works. Portsmouth, NH: Heinemann.

Giles, G. (2008). Wanted, male models: There's a good reason why boys don't read. School Library Journal, 54(12), 48-49.

Grayson, J. L., \& Alvarez, H. K. (2008). School climate factors relating to teacher burnout: A mediator model. Teaching and Teacher Education, 24(5), 1349-1363.

Grossman, P. L., Valencia, S.W., Evans, K., Thomspon, C., Martin, S., \& Place, N. (2000). Transitions into teaching: Learning to teach writing in teacher education and beyond. Journal of Literacy Research, 32(4), 631-662.

Gu, Q., \& Day, C. (2007). Teacher's resilience: A necessary condition for effectiveness. Teaching and Teacher Education, 23(8), $1302-1316$

Gurian, M., \& Stevens, K. (2005). The minds of boys: Saving our sons from falling behind in school and life. San Francisco: Joseey-Bass.

Heath, S. B. (1982). What no bedtime story means: Narrative skills at home and school. Language in Society, 11(1), 49-76.

Heath, S. B., \& Street, B. V. (2008). Ethnography: Approaches to language and literacy research. New York: Teachers College Press.

Kelly, P. (2007). Boys, Books, Blokes and Bytes. APLIS 20(2), 72-83.

Klinger, D., Shulha, L., \& Wade-Woolley, L. (2009). Towards an understanding of gender differences in literacy achievement. Toronto, ON: The Education Quality and Accountability Office (EQAO). www.eqao.com

Kugler, J., \& Flessa, J. (2007). Leadership for parent and community involvement: Lessons from recent research in Ontario. Education Today, 19(1), 1-6.

Leithwood, K., \& McAdie, P. (2007). Teacher working conditions that matter. Education Canada, 47(2), 42-45.

Lietz, P. (2006). A meta-analysis of gender differences in reading achievement at the secondary school level. Studies in Educational Evaluation, 32, 317-344.

McDaniel, C. (2004). Critical literacy: A questioning stance and the possibility for change. The Reading Teacher, 57(5), $472-481$.

McLean, C. A., \& Rowsell, J. (2013). (Re)designing literacy teacher education: A call for change. Teacher Education, 24(1), 126.

MacLure, M. (2003). Discourse in educational and social research. Philadelphia, PA: Open University Press.

Ontario Ministry of Education. (2004). Me read? No way! A practical guide to improving boys' literacy skills. Toronto: Queen's Printer.

Newkirk, T. (2002). Misreading masculinity: Boys, literacy, and popular culture. Portsmouth, NH: Heineman.

Parker, D. C. (2010). Writing and becoming (a teacher): Teacher candidates' literacy narratives over four years. Teaching and Teacher Education, 26, 1249-1260.

Parkinson, H., \& Stooke, R. (2012). Other duties as assigned: The hidden work of reading and writing assessments in two primary classrooms. Language and Literacy, 14(1), 59-77.

Gray, J., Peng, W., Steward, S., \& Thomas, S. (2004). Towards a typology of gender-related school effects: Some new perspectives on a familiar problem. Oxford Review of Education, 30(4), 529-550.

Slavin, R., Lake, C., Davis, S., \& Madden, N. (2009). Effective programs for struggling readers: A best evidence synthesis. Baltimore MD: Johns Hopkins University, Center for Research and Reform in Education (CRRE). www.bestevidence.org.uk

Smith, D. E. (2002). Institutional ethnography. In T. May (Ed.), Qualitative Research in Action (pp. 17-52). London, UK: Sage. Smith, D. E. (2005). Institutional ethnography: A sociology for the people. Oxford, UK: AltaMira Press. 
Smith, D. E. (2006). Institutional ethnography as practice. Lanham, MD: Rowman \& Littlefield Publishers.

Smith, M., \& Wilhelm, J. (2003). "Reading don't fix no Chevys": Literacy in the lives of young men. Teachers College Record, 105(1), 19-21.

Sokal, L., Thiem, C., Crampton, A., \& Katz, H. (2009). Differential effects of male and female reading mentors based on boys' gendered views of reading. Canadian Journal of Education, 32(2), 245-270.

Spence, C. (2008). The joys of teaching boys: Igniting writing experiences that meet the needs of all students. Markham, ON: Pembroke.

Valli, L., \& Buese, D. (2007). The changing roles of teachers in an era of high-stakes accountability. American Educational Research Journal, 44(3), 519-558.

Wasik, B. (2011). Volunteer tutoring programs in reading: A review. Reading Research Quarterly, 33(3), 266-291.

Wasick, B. (1998). Using volunteers as reading tutors: Guidelines for successful practices. The Reading Teacher, 51(7), 562-570.

White, S., \& Hill, H. (2008). What's the difference and where is the evidence? Investigating student teachers learning about literacy in a school based vs university based experience. Conference paper proceedings of the 2008 Australian Teacher Education Association Conference.

Wilfong, L. G. (2008). Building fluency, word-recognition ability, and confidence in struggling readers: The Poetry Academy. The Reading Teacher, 62(1), 4-13. 